character ; they are strong and easily reversed, and in all of them the first doublet is situated on the less refrangible side of the spectrum, and all the others in the violet and ultra-violet. The series shift towards the less refrangible side with increasing atomic weight.

For further details the reader is referred to the following memoirs :-Kayser and Runge, "Ueber die Spectren der Elemente," Abhandl. der Berl. Akademie, 1890-92; Rydberg, "Recherches sur la constitution des spectres d'émission des élements chimiques," Kongl. Svenska Vetenskaps-Akademiens Handlingar, Bandet 23, No. II, 1890.

C. RUNGE.

\section{ABERRANT FOSSIL UNGULATES OF SOUTH AMERICA.}

$\mathrm{T}^{1}$

ILL within the last few years palæontologists and zoologists were being continually startled by the discovery of strange forms of extinct Ungulates which rewarded the researches conducted in the Tertiary rocks of the United States. The animals thus brought to the notice of the scientific world have, to a very large extent, modified our conceptions of the relationships of the various groups of hoofed or Ungulate Mammals to one another; and have led to the very general adoption of the view of the ordinal unity of all these multifarious types. Several of them, indeed, so far as we may judge from their mere skeletons, indicate signs of a transition between the Perissodactyle and Proboscidean modifications of Ungulate structure ; but none of them tend in the least degree to break down the hard and fast line of demarcation between the Perissodactyle (odd-toed) and Artiodactyle (even-toed) modifications, which is maintained throughout all the known Tertiary deposits of the Old World. Moreover, after a little "shaking down," the whole of these North American Ungulates, with the exception of the curious Rodent-like Tillotherium, fall fairly well into their places in the Ungulate order; although some of the earlier and smaller types present indications of close affinity with the common stock from which we may presume both Ungulates and Carnivores to have taken origin.

At the present time the wave of discovery of new forms appears to be passing from the northern to the southern half of the New World; so that while the palæontologists of the United States are to a great extent engaged in the important task of revising and completing the preliminary work of the last twenty years, their confrères in Argentina are almost flooding scientific literature with descriptionssometimes, it is to be feared, rather crude and hasty ones -of a number of new or hitherto imperfectly known forms of extinct mammals. This descriptive work has been mainly undertaken by Messrs. Ameghino, Burmeister, and Moreno. Unfortunately, however, the greater part of it is still in the form of preliminary notices, unaccompanied by illustrations; while on several points the three describers above mentioned are by no means in accord, and it is quite clear that unnecessary names have frequently been published. There is, indeed, one large illustrated work published by Dr. Ameghino; but since, so far as we are aware, there is only a single copy (in the Natural History Museum) in England, palæontologists have not the opportunity of paying it that attention in private study which its importance demands.

In spite, however, of these drawbacks, the information at present before us-imperfect though it be-introduces us to several groups of extinct Ungulates totally unlike any found in all the rest of the world put together, and which are of especial interest as tending to a certain extent to break down the distinction between Perissodactyles and Artiodactyles. It should be observed, before proceeding further, that the explorations conducted in NO. I I 74, VOL. 45]
Patagonia and various parts of Argentina have shown that the deposits containing mammalian remains, instead of being exclusively of Pleistocene age, comprise a large portion of the Tertiary period, probably extending down at least as far as the Oligocene; although the exact correlation of the different beds with European deposits is probably premature.

With these preliminary observations, and asking our readers at the same time to bear in mind that a considerable part of our knowledge is still in a very imperfect and crude condition, we propose to glance at some of the peculiarities presented by the more remarkable forms of Ungulates described from the deposits in question.

Since the date of the publication of the results of Darwin's voyage in the Beagle, we have been gradually acquiring a knowledge of the structure of that remarkable South American Ungulate known as Macrauchenia, of which the complete osteology has been described by Burmeister. This animal, which had the general proportions and size of a horse, conforms in several respectsmore especially in having three-toed feet, in which the middle (third) digit is symmetrical in itself-so markedly with the Perissodactyles, that by common consent it has been generally regarded as an extremely aberrant member of that group. The molar teeth are, indeed, more like those of the Rhinoceros and Palæotherium than of any other Old World Ungulates, while the infolding of the enamel of the crowns of the incisors is a character known elsewhere only in the horses. The absence of any gap in the dental series, and the nearly even height of the teeth, are characters in which Macrauchenia agrees with the Old World Anoplotherium. Perissodactyle affinities are indicated by the presence of a third trochanter on the femur; but in certain peculiarities in the anklejoint this animal differs from all typical Perissodactyles, and agrees with the Artiodactyles. Moreover, a certain peculiarity of structure in the vertebræ of the neck is repeated elsewhere only in the camels and llamas, which form an isolated group of Artiodactyles. In the complete closure of the orbit by bone, Macrauchenia resembles the horses and many Artiodactyles; but in the narial aperture being situated on the top of the skull between the orbits (whence the nostrils were probably produced in the form of a proboscis), it is absolutely peculiar.

There are thus many indications that, while Macrauche$n i a$ is a specialized form that can in no sense be regarded as the ancestral type from which Perissodactyles and Artiodactyles have originated, it retains certain generalized features which were probably directly derived from such ancestral stock.

Among the Ungulates discovered in Patagonia is one named Proterotherium, which was at one time referred to the Artiodactyles, but subsequently placed among the Perissodactyles. In the skull, so far as can be gathered from Ameghino's description, the orbit is closed, as in Macrauchenia, but the narial aperture appears to have had the normal position. The molar teeth are so like those of true Perissodactyles that they were originally described under the name of Anchitherium; but the rest of the dentition is very peculiar. Thus, in the upper jaw there appears to have been only a single pair of incisors in the premaxillæe, these being pyramidal and obliquely truncated like the canines of the pigs; and as there were no canines, it may be inferred that there was a long toothless interval in the jaw. In the lower jaw there were two pairs of incisors, and no canines. The lower molar teeth were inserted by four distinct roots-a feature unknown in any existing Perissodactyle, although occurring in the pig. In the limbs, both the front and hind feet were furnished with three complete toes, much resembling those of Hipparion; the ankle-joint is, however, said to resemble that of the Artiodactyles. We have no information as to the third trochanter of the femur. On the whole, this genus appears to indicate a 
Perissodactyle-like Ungulate, somewhat more specialized as regards its dentition than Macrauchenia, but exhibiting stronsly-marked Artiodactyle affinities in the ankle-joint.

Still more remarkable are the generalized affinities displayed by the group known as the Toxodonts, of which the first representative was also discovered during Darwin's memorable voyage. These Ungulates cannot be included in either the Perissodactyla or Artiodactyla, and, therefore, come nearer the original generalized Ungulate stock than the animals already noticed. Toxodon, from the Pleistocene of Argentina, was of the approximate size of a Hippopotamus, and its osteology is tolerably well known. It takes its name from the curvature of the molar teeth, which approximate in structure to those of the Rhinoceros, and, like the incisors, have ever-growing roots. The front teeth are separated from the cheek-teeth by a considerable interval; the upper dental series being reduced in number by the loss of the outermost incisors and the canines, and the lower by the disappearance of the first premolars ; the lower canine is, moreover, rudimentary. The feet conform to the Perissodactyle type in having three toes, of nearly equal size, and also in the interlocking of the bones of the upper and lower rows of the wrist- and ankle-joints. In the absence of a third trochanter to the femur, and also in the articulation of the fibula with the calcaneal bone of the ankle, as well as in the structure of the palatal and tympanic regions of the skull, Toxodon is, however, constructed on a decided Artiodactyle type ; so that its characters are to a great extent intermediate between the existing members of the two groups.

Going back to the earlier Tertiaries of Argentina and Patagonia, a number of Ungulates allied to Toxodon, but with much more generalized characters, have been brought to light. The skulls from Patagonia brought back by Darwin, and named Nesodon, also belong to this same generalized group. In Nesodon there is the full complement of 44 teeth; and the same formula also obtains in the recently described Protoxodon, in which the feet are known to have been tridactylous in both limbs, although retaining rudiments of the metacarpals of the first and second digits, and being of a longer and more slender type than in Toxodon. The allied animals described as Acrotherium, some of which were about the size of a pig, present a peculiarity totally unknown among other Ungulates; and, indeed, in any Eutherian Mammals except some individuals of the small African long-eared fox (Otocyon). This peculiarity consists in the presence of eight cheek-teeth on either side of each jaw ; the constancy of this character being proved by its occurrence in a considerable number of specimens. Whereas, however, in Otocyon the eight cheek-teeth are reckoned as four premolars and four true molars, in Acrotherium there are said to be five premolars and three true molars. If this interpretation be correct, it is difficult to point out a probable derivation for this most remarkable type of dentition, since no other heterodont mammals are definitely known to have more than four premolars.

If, however, the cheek-teeth really prove to be four premolars and four true molars, there might be a possibility of direct inheritance of the fourth molar of the Marsupials, although even then there is the difficulty that none of the Lower Eocene Ungulates of the United States are known to have possessed more than three of these teeth. And the probability accordingly suggests itself that the additional tooth may be an acquired redundancy. There are a number of other more or less closely allied types which have received distinct generic names, such as Colpodon and Adinotherium, but it is at present somewhat difficult to realize all their distinctive features and peculiarities. One genus, however, if the specimen on which it was established is normal, is so remarkable as to call for special notice; and taken together with Acrotherium seems to show that these South American Ungulates ran riot in the disregard of all rules as to the number and arrangement of their teeth. The genus in question is Trigodon, founded upon the lower jaw of an animal about the size of a pig, but evidently related in the structure of its cheek-teeth to Toxodon. In this mandible the middle of the extremity of the long and narrow symphysis is occupied by a single cylindrical incisor tooth, flanked by a pair of larger incisors, and these, again, by the still larger triangular canines. If normal (and from Dr. Moreno's description and figure it would seem to be so) this single median incisor is totally unique in the whole mammalian class.

A still more remarkable and puzzling group is typically represented by the long-known Typotherium from some of the Tertiaries of Argentina, which, while presenting many dental characters connecting it with the Toxodonts, has upper incisors resembling those of the Rodents; with most of which it also agrees in the presence of clavicles, which are invariably absent in all true Un rulates. The number of the teeth is similar to that obtaining in many Rodents, with the exception that there are two pairs of lower incisors. An allied type has, however, three pairs of these teeth, thus departing further from the Rodent type ; and the skull of both genera is constructed on the Ungulate plan. All the teeth are rootless. From other beds in Argentina we have the genus described as Hegetotherium, which, while having rootless teeth, differs from Typotherium in possessing the whole typical series of 44 , without any marked interval between them. Here, then, we have almost entirely lost the Rodent features which are so marked in Typotherium, and thus revert nearer to a normal Ungulate type; it is unknown whether clavicles were present. Still more generalized is an allied group typified by Interatherium, in which the dentition is always complete, the anterior premolars have distinct roots, and the incisors conical roots. This genus and the allied Protypotherium thus appear to be connected both with Typotherium and the Toxodonts; the specific name rodens applied to one of the species of Protypotherium apparently indicating the existence of Rodentlike upper incisors.

The existence of these intermediate forms renders it exceedingly difficult to come to any satisfactory conclusion as to whether Typotherium really has any genetic affinity with the Rodents (among which it was placed by the late Mr. Alston) ; for if there be such relationship it would seem to imply the descent of all Rodents from a form more or less closely allied to Interatherium - a view which can scarcely be maintained.

That these Typotheroids were, however, in some manner connected with the Toxodonts is tolerably clear; and there are nearly equally clear indications of a more or less distant connection between the Toxodonts and the Macrauchenias. The most probable explanation of the latter relationship is that both groups took origin from generalized Ungulates allied to those found in the Eocene of the United States, and known as the Condylarthra, which appear to have been the common ancestral stock of both the Artiodactyle and Perissodactyle modifications of the order. On this view the retention of characters common to both the groups last-mentioned by the Toxodonts and Macrauchenias is readily accounted for; the Macrauchenias having acquired sufficiently well-marked Perissodactyle characters to admit of their inclusion in that group, while the Toxodonts cannot be placed in either of the two existing divisions of typical Ungulates. Having thus diverged at an early epoch (perhaps in the neighbourhood of Central America) from the original generalized Ungulate stock, the ancestral Toxodonts and Macrauchenias become the dominant forms in South America, where they appear to have developed into such numerous and unexpected modifications of struc-

No. I I 74 , vOL. 45] 
ture, as to render the task of deciphering their mutual relationships and determining their exact systematic positions an exceedingly difficult, if not an impossible one. At the same time, however, it does not appear to us that the existence of these puzzling and aberrant types need interfere in the least degree with the commonly-accepted classification of the Ungulates, although there may be legitimate doubt as to the propriety of including the Macrauchenias among the Perissodactyles, instead of retaining them with the Toxodonts as a special group, exhibiting on the one hand many generalized features, coupled with extreme specialization in other respects.

R. L.

\section{THE CHANGEFULNESS OF TEMPERATURE AS AN ELEMENT OF CLIMATE.}

$\mathrm{NE}$ of the features in which the climates of great continents most contrast with those of oceanic islands, and those of higher latitudes with the climates of the tropics, is the greater range through which the temperature varies between night and day, and between winter and summer. Another, perhaps not less important, is the greater changefulness of the temperature from day to day. Both of these are comprised under the general expression variabiiity of temperature, ${ }^{1}$ and they are similar in their effects on living organisms, but they depend on very different causes, and in their local association are often manifested in very different degrees; places with a great annual and diurnal range of temperature, displaying great constancy of climate at any given season of the year, while others, at which the former variations are moderate in amount, are, nevertheless, subject to irregular vicissitudes of considerable magnitnde. The Punjab and Sind may be cited as examples of the former class, Western and Central Europe of the latter.

Now, although from a sanitary point of view these two kinds of variation are of equal importance, the degrees in which they have respectively engaged the attention of climatologists and others are strikingly different. While the daily and annual range of temperature of all the more important and many minor places that have furnished meteorological registers are now well known, or are easily ascertainable from published records, the first systematic inquiry into the changefulness of temperature as an element of climate was that made by Prof. Hann in a memoir published in the Sitzungsberichte of the Vienna Academy of Sciences in I 875. In this paper, Dr. Hann tabulated the results of ninety stations, seven of which are situated in the southern hemisphere, and the remainder chiefly in Europe, Siberia, Canada, and the United States. The extraction of the data was not a little laborious, since it consisted in taking out from the daily registers, of generally from five to ten years, the differences of the mean temperatures of every pair of successive days throughout the whole period; then classifying them according to algebraic sign, as rises or falls of temperature, and also, in certain cases, according to their incremental values. The means of these different categories were then taken month by month, and the results are given in numerous tables in the memoir. The changefulness of temperature at any given place is the general mean of all changes during the period considered, irrespective of their being rise or fall. As instances of these, I take the following three stations, representing respectively the climates of Siberia, England, and Canada. They show

I The term "variability" of temperature, adopted by Mr. Scott for the element now in question, has been already used in so many different senses, that in this paper 1 have adopted in preference the term "changefulness," which is not open to the same objection. the average change of any two consecutive days on the Fahrenheit scale.

\begin{tabular}{|c|c|c|c|c|}
\hline & & Barnaul. & Oxford. & Toronto. \\
\hline $\begin{array}{ll}\text { January } & \ldots \\
\text { February } & \ldots \\
\text { March } & \ldots \\
\text { April } & \ldots \\
\text { May } & \ldots \\
\text { June } & \ldots \\
\text { July } & \ldots \\
\text { August } & \ldots \\
\text { September... } \\
\text { October } & \ldots \\
\text { November } & \ldots \\
\text { Necember } & \ldots\end{array}$ & \begin{tabular}{l|}
$\ldots$ \\
$\ldots$ \\
$\ldots$ \\
$\ldots$ \\
$\ldots$ \\
$\ldots$ \\
$\cdots$ \\
$\ldots$ \\
$\ldots$ \\
$\ldots$ \\
$\ldots$ \\
$\ldots$
\end{tabular} & $\begin{array}{r}8 \cdot 8 \\
8 \cdot 5 \\
7 \cdot 2 \\
4 \cdot 7 \\
5 \cdot 6 \\
4 \cdot 3 \\
3 \cdot 4 \\
3 \cdot 2 \\
4 \cdot 5 \\
5 \cdot 6 \\
9 \cdot 0 \\
10 \cdot 1\end{array}$ & $\begin{array}{l}3 \cdot 4 \\
3 \cdot I \\
2 \cdot 9 \\
2 \cdot 9 \\
3 \cdot 1 \\
2 \cdot 7 \\
2 \cdot 3 \\
2 \cdot 5 \\
2 \cdot 5 \\
3 \cdot 4 \\
3 \cdot 6 \\
3 \cdot 8\end{array}$ & $\begin{array}{l}6 \cdot 8 \\
6 \cdot 8 \\
4 \cdot 9 \\
4 \cdot 0 \\
3 \cdot 8 \\
3 \cdot 8 \\
3 \cdot 6 \\
3 \cdot 2 \\
4 \cdot 5 \\
4 \cdot 1 \\
4 \cdot 5 \\
6 \cdot 7\end{array}$ \\
\hline Year & $\ldots$ & $6 \cdot 3$ & $3^{\cdot I}$ & 47 \\
\hline
\end{tabular}

These three stations serve to illustrate the fact, amply confirmed by the general tables, that temperature is subject to greater and more rapid changes in the winter than in the summer; either December or January being, as a rule, the month of greatest variability.

Since the publication of this memoir, the inquiry thus started by Dr. Hann has been followed up by several writers with especial reference to particular countries. Prof. O. Döring, for instance, has thus discussed the statistics of the Argentine Republic; Herr E. Wahlén, those of 18 stations in Russia; Dr. V. Kremer, those of 57 stations in Northern Germany; and Mr. Robert Scott, those of 7 observatories in the British Isles, at which the temperature has been recorded by thermographs since I 869. These are Valentia, Armagh, Glasgow, Aberdeen, Falmouth, Stonyhurst, and Kew. At all these stations the variation was found to be less than at Oxford; but this may be partly due to the longer period ( 5 years) over which the records extend, and partly also to the fact that the daily means compared are those of the twentyfour hourly measurements of the thermograph curve, whereas the Oxford register was for Io years only, and the observations less numerous. On the general average of the year, it was greatest at $\operatorname{Kew}\left(2^{\circ} \cdot 7\right)$, and least at Falmouth and Valencia $\left(1^{\circ} .9\right)$.

Finally, Dr. Hann has resumed the subject in a memoir published in the Transactions of the Vienna Academy, ${ }^{1}$ in which he discusses the temperature records of 66 stations in the Austrian Empire and the adjacent territories, of which one-half extend over from 10 to 20 years, and the majority of the remainder over at least five years; all, however, are corrected to the period I $871-80$. In the case of Vienna, not less than 9i years have been included in the reckoning, and this register affords the means of comparing the results of any decade with those of a long period.

The first point that stands out in the results of this discussion is that even a period of ten years is insufficient to give more than an approximate value. The general mean change at Vienna, between any two consecutive days, is $3^{\circ} 4 \mathrm{~F}$, but in the decade $186 \mathrm{I}-70$ it was only $3^{\circ} 26$, whereas in the decades $180 \mathrm{I}-10$ and I $871-80$ it averaged $3^{\circ} .53$. The means of the individual months show much greater variation; that of December especially, ranging between $3^{\circ} \cdot 2$ and $4^{\circ} \cdot 3$ in different decennia, or through 30 per cent. of the general mean for the month. It is evident that when computed from shorter periods than ten years the discrepancies will

I "Die Veränderlichkeit der Temperatur in Oesterreich," von J. Hann, W.M.K. Akad., aus dem lviii.Bande der Mat. Naturwiss. Classe der $h$. Akad. d. Wissenschaften. 